\title{
Analisa Komparasi Algoritma Decision Tree C4.5 dan Nä̈ve Bayes untuk Prediksi Churn Berdasarkan Kelas Pelanggan Retail
}

\author{
Ni Wayan Wardani ${ }^{1, *}$, Ni Kadek Ariasih ${ }^{2}$
}

${ }^{12}$ STMIK STIKOM Indonesia

\author{
A R T I C L E I N F O \\ Article history: \\ Received 19 July 2019 \\ Received in revised form \\ 16 August 2019 \\ Accepted 19 September \\ 2019 \\ Available online 30 October \\ 2019 \\ Kata Kunci: \\ Prediksi Churn, RFM, C4.5, \\ Naïve Bayes \\ Keywords: \\ Churn prediction, RFM, C4.5 \\ Nä̈ve Bayes
}

\begin{abstract}
A B S T R A K
Pelanggan adalah salah satu aset utama bagi perusahaan ritel. Perusahaan harus dapat mengenali bagaimana karakter pelanggan mereka sehingga mereka dapat mempertahankan pelanggan yang sudah ada agar tidak berhenti membeli dan pindah ke perusahaan ritel yang bersaing (churn). Salah satu model yang tepat untuk mengenali karakter pelanggan adalah model RFM (Recency, Frekuensi, Moneter). Model RFM mampu menghasilkan kelas pelanggan dan di setiap kelas pelanggan dapat dianalisis atau diprediksi dengan konsep data mining apakah pelanggan tetap sebagai pelanggan atau churn. Data yang digunakan berasal dari data pelanggan dan data penjualan di UD. Mawar Sari. Kelas pelanggan UD Mawar Sari yang dihasilkan dari model RFM adalah Dormant, Everyday, Golden dan Superstar. Konsep data mining dengan membangun model prediksi dalam penelitian ini menggunakan algoritma Decision Tree C4.5 dan Naïve Bayes. Di semua kelas pelanggan kinerja Algoritma Naïve Bayes lebih baik daripada Algoritma Decision Tree C4.5 dengan Recall 95,92\%, Precision $84,15 \%$, dan Accuracy $83,49 \%$ dan kelas pelanggan yang memiliki potensi churn tinggi adalah Dormant B, Dormant $\mathrm{E}$, dan Dormant F.
\end{abstract}

\section{A B S T R A C T}

Customers are one of the main assets for retail companies. Companies must be able to recognize how the character of their customers is so that they can retain existing customers so as not to stop buying and move to competing retail companies (churn). One of the right models for recognizing customer characters is the RFM (Recency, Frequency, Monetary) model. RFM model is able to produce customer classes and in each customer class can be analyzed or predicted with the concept of data mining whether the customer remains as a customer or churn. The data used comes from customer data and sales data at UD. Mawar Sari. UD Mawar Sari customer class produced from the RFM model are Dormant, Everyday, Golden and Superstar. The concept of data mining by building prediction models in this study uses the Decision Tree C4.5 algorithm and Naïve Bayes. In all customer classes Naïve Bayes Algorithm performance better than Decision Tree C4.5 Algorithm with Recall $95.92 \%$, Precision $84.15 \%$, and Accuracy $83.49 \%$ and customer classes that have high potential for churn are the Dormant B, Dormant E, and Dormant F.

\footnotetext{
${ }^{1}$ Corresponding author.

E-mail addresses: niwayan.wardani@stiki-indonesia.co.id (Ni Wayan Wardani)
} 


\section{Pendahuluan}

Pertumbuhan bisnis retail saat ini menunjukkan trend yang positif, tidak hanya bertumbuh di kota-kota besar tetapi juga di kota-kota kecil bahkan sampai pelosok desa. Dari pertumbuhan tersebut, tentunya memunculkan persaingan bisnis retail yang sangat ketat. Pelanggan akan dengan sangat mudah memilih toko retail yang terbaik buat mereka. Hal tersebut menjadikan perusahaan retail tidak hanya berfokus pada pengembangan produk dan layanan tetapi juga berfokus pada pelanggan dengan mampu menciptakan pengalaman personal pelanggan sehingga dapat meningkatkan loyalitas pelanggan.

Menurut Emmet C. Murphy dan Mark A. Murphy dalam buku Leading On The Edge of Chaos bahwa memperoleh pelanggan baru menghabiskan biaya lima kali lipat dari biaya untuk memuaskan dan mempertahankan pelanggan lama, sementara itu peningkatan sebanyak 2\% dalam mempertahankan pelanggan (customer retention) punya dampak terhadap laba seperti memangkas biaya sebesar $10 \%$. Untuk mempertahankan pelanggan lama, tentunya perusahaan perlu mengetahui karakter - karakter pelanggan mereka sehingga dapat mengambil langkah - langkah strategis, dengan harapan pelanggan akan semakin loyal dan tidak berpindah ke perusahaan pesaing (churn).

Dalam penelitian ini akan dilakukan identifikasi karakter pelanggan dan melakukan prediksi churn berdasarkan karakter pelanggan yang dimiliki perusahaan retail UD. Mawar Sari. Metoda yang digunakan untuk mengidentifikasi karakter pelanggan dengan menghasilkan kelas pelanggan adalah metoda RFM (Recency, Frequency, Monetary). Data yang digunakan untuk mendapatkan fitur recency, frequency, dan monetary adalah berasal dari data pelanggan dan transaksi pelanggan. Data setiap kelas pelanggan digunakan untuk pembangunan model prediksi customer churn menggunakan Algoritma Decision Tree C4.5 dan Algoritma Nä̈ve Bayes. Algoritma Decision Tree C4.5 merupakan salah satu teknik klasifikasi dalam data mining. Kefleksibelan membuat metoda ini atraktif, khususnya karena memberikan keuntungan berupa visualiasasi keuntungan berupa visualiasi saran dalam bentuk pohon keputusan yang membuat prosedur prediksinya dapat diamati. Algoritma Naïve Bayes adalah suatu klasifikasi yang bekerja berdasarkan teori probabilitas yang memandang semua fitur dari data sebagai bukti dalam probabilitas.

\section{Metode}

Penelitian ini diselesaikan dengan melalui tahapan - tahapan yang ditunjukkan pada Gambar 1.

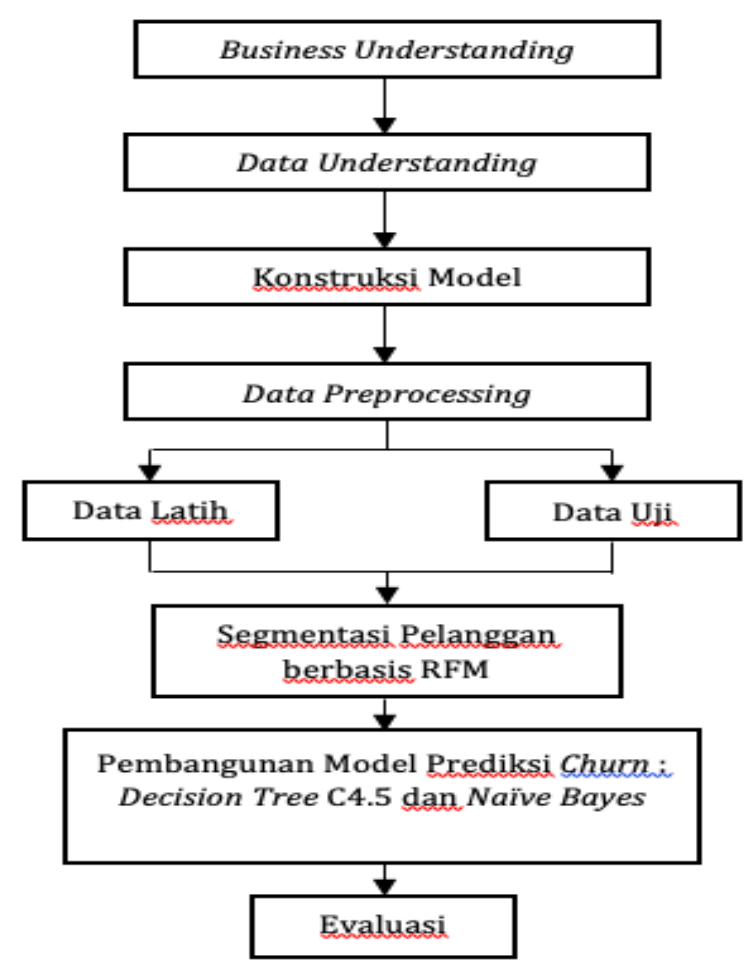

Gambar 1. Diagram Ikhtisar Penelitian 


\section{Business Understanding}

Business understanding adalah pemahaman terhadap tujuan bisnis, penilaian situasi dan menerjemahkan tujuan bisnis ke dalam tujuan data mining. Dalam penelitian ini, salah satu tujuan dari data mining adalah untuk mendukung proses customer retention adalah mengidentifikasi karakter pelanggan dan membuat prediksi customer churn.

\section{Data Understanding}

Pada tahap ini dilakukan proses pengumpulan data, kemudian melakukan analisa data serta melakukan evaluasi kualitas data yang digunakan dalam penelitian ini. Dari proses perijinan data yang diajukan, diperoleh data transaksi pelanggan pada tahun 2015 sebanyak 30.765 record data, tahun 2016 sebanyak 64.008 record data dan pada tahun 2017 sebanyak 26.316 data.

\section{Konstruksi model}

Konstruksi model dalam penelitian ini adalah menentukan data window dan forecasting window. Data window adalah kerangka waktu untuk variable input yang digunakan untuk mengkonstruksi model. Forecasting window adalah rentang waktu perilaku churn pelanggan yang akan diprediksi.

Dalam penelitian ini, kerangka waktu yang digunakan untuk konstruksi model data window di data latih adalah data transaksi pelanggan selama 9 bulan (Juli 2015 sd Maret 2016), sedangkan rentang waktu perilaku churn pelanggan sebagai forecasting window di data latih yang digunakan adalah data transaksi pelanggan selama 3 bulan (April 2016 sd Juni 2016).

Pada data uji, kerangka waktu yang digunakan untuk konstruksi model data window adalah data transaksi pelanggan selama 9 bulan (Mei 2016 sd Februari 2017), sedangkan rentang waktu perilaku churn pelanggan sebagai forecasting window yang digunakan adalah data transaksi pelanggan selama 3 bulan (Maret 2017 sd Mei 2017).

\section{Data Preprocessing}

Data Preprocessing meliputi memilih data pembersihan data, dan mengelompokkan atribut atribut atau field yang telah terpilih menjadi 1 tabel (Tabel 1).

Tabel 1. Data parsial dari Database UD. Mawar Sari

\begin{tabular}{ll}
\hline Field & Keterangan \\
\hline Id_Pelanggan & Kode Pelanggan \\
TglBeliAkhir & Menandakan recency, merupakan tanggal transaksi yang dilakukan oleh pelanggan \\
FrekuensiBeli & Menandakan frequency, merupakan jumlah transaksi selama periode yang ditentukan \\
TotalBeli & Menandakan monetary, merupakan jumlah uang selama periode yang ditentukan \\
\hline
\end{tabular}

\section{Data Latih}

Pada data latih, data window sebanyak 30.765 record, sedangkan forecasting window sebanyak 17.915 record.

\section{Data Uji}

Pada data uji, data window sebanyak 51.714 record, forecasting window sebanyak 14.511 record.

\section{Segmentasi Pelanggan Berbasis RFM}

Segmentasi adalah proses membagi pelanggan menjadi beberapa cluster dengan kategori loyalitas pelanggan untuk membangun strategi pemasaran. Segmentasi pelanggan dibagi menjadi 6 karakteristik berdasarkan nilai RFM sebagai berikut :

\section{Superstar}

Pelanggan dengan loyalty yang tinggi dengan nilai monetary, frequency dan mempunyai transaksi paling tinggi

\section{Golden}

Pelanggan yang mempunyai nilai monetary tertinggi kedua, frequency yang tinggi dan mempunyai ratarata transaksi

3. Typical

Pelanggan yang mempunyai rata-rata nilai monetary dan rata-rata transaksi

4. Occational

Pelanggan yang mempunyai nilai monetary terendah kedua setelah dormant, nilai recency paling rendah dan transaksi paling tinggi. 


\section{Everyday}

Pelanggan yang memiliki peningkatan transaksi, transaksi yang rendah, dan mempunyai nilai monetary sedang sampai rendah.

6. Dormant

Pelanggan yang mempunyai frequency dan monetary yang paling rendah dan recency yang paling rendah.

Dalam pembentukan model RFM, diterapkan RFM skor satu sampai tiga (1-3) pada domain nilai recency, frequency, dan monetary di setiap pelanggan. Skor 3 adalah nilai tertinggi dan skor 1 adalah nilai terendah. Skor akhir dihitung dari kombinasi setiap skor pada atribut. Pemberian skor sendiri akan memudahkan proses segmentasi pelanggan.

Nilai recency, frequency,monetary dibagi menjadi 3 bagian dengan nilai 3,2 dan 1. Nilai recency dihitung berdasarkan tanggal transaksi terakhir atau interval waktu transaksi terakhir dengan saat ini. Nasabah dengan tanggal transaksi terbaru mempunyai nilai 3 sedangkan nasabah dengan tanggal transaksi terjauh di masa lalu mempunyai nilai 1. Begitu juga dengan nilai frequency, nasabah yang sering bertransaksi mempunyai nilai frequency yang tinggi, yaitu 3. Sedangkan nasabah yang jarang bertransaksi mempunyai nilai 1 . Nasabah yang mempunyai total nilai transaksi terbesar mempunyai nilai monetary yang tinggi, dengan nilai 3. Sebaliknya nasabah yang mempunyai total nilai transaksi terkecil mempunyai nilai monetary yang rendah yaitu 1 . Rentang skor dan domain nilai didapatkan dari hasil wawancara dengan manajemen UD. Mawar Sari dan hasil bagi 3 dari nilai atribut terkecil ke nilai atribut tertinggi. Skor dan domain nilai untuk atribut recency, frequency, monetary ditunjukkan dalam Tabel 2 berikut ini :

Tabel 2. Skor dan Domain Nilai RFM

\begin{tabular}{lll}
\hline Atribut & Skor & Domain nilai \\
\hline & 1 & $r>150$ hari \\
Recency & 2 & 61 hari $\leq r \leq 150$ hari \\
& 3 & $0 \leq r \leq 60$ hari \\
Frequency & 1 & $0<f \leq 30$ \\
& 2 & $31 \leq f \leq 60$ \\
Monetary & 3 & $f>60$ \\
& 1 & $0<m \leq$ Rp. 1.500 .000 \\
& 2 & Rp. $1.500 .000<m \leq$ Rp. 3.500 .000 \\
\hline
\end{tabular}

\section{Pembangunan Model Prediksi Customer Churn dengan Decision Tree C4.5 dan Naïve Bayes}

Model yang digunakan untuk membangun model prediksi customer churn dalam penelitian ini adalah algoritma Decision Tree C4.5 dan Nä̈ve Bayes. Data hasil pemodelan RFM masih dalam bentuk numerik, sedangkan pemodelan dengan algoritma Decision Tree C4.5 membutuhkan data berbentuk kategorikal, sehingga data hasil pemodelan RFM harus dikonversi ke dalam bentuk kategorikal. Tabel 3 adalah klasifikasi atribut untuk nilai data hasil konversi yang akan digunakan untuk memprediksi customer churn.

Tabel 3. Klasifikasi Atribut dengan Variabel Kategorikal

\begin{tabular}{llll}
\hline Atribut & Skor & Domain nilai & Variabel kategorikal \\
\hline \multirow{2}{*}{ Recency } & 1 & $r>150$ hari & Lama \\
& 2 & 61 hari $\leq r \leq 150$ hari & Agak lama \\
& 3 & $0 \leq r \leq 60$ hari & Baru saja \\
& 1 & $0<f \leq 30$ & Jarang \\
Frequency & 2 & $31 \leq f \leq 60$ & Agak sering \\
& 3 & $f>60$ & Sering \\
& 1 & $0<m \leq$ Rp. 1.500 .000 & Rendah \\
Monetary & 2 & Rp. $1.500 .000<m \leq$ Rp. 3.500 .000 & Sedang \\
& 3 & $m>$ Rp. 3.500 .000 & Tinggi \\
\hline
\end{tabular}

Setelah ditentukan skor dan domain nilai pada recency, frequency, dan monetary maka akan didapatkan skor akhir RFM dan penentuan label pelanggan. 
Terdapat $27(3 \times 3 \times 3)$ kombinasi skor akhir RFM. Skor akhir RFM yang tertinggi adalah 333 dan yang terendah adalah 111 .

Nasabah dengan skor akhir 333 merupakan nasabah yang dengan tingkat keloyalan yang tinggi sedangkan nasabah dengan skor akhir 111 merupakan nasabah dengan tingkat keloyalan yang rendah.

Tabel 4. Deskripsi Variabel Kategorikal dan Label Pelanggan

\begin{tabular}{|c|c|c|c|c|c|}
\hline \multirow[b]{2}{*}{ Kelas } & \multicolumn{3}{|l|}{ Skor } & \multirow{2}{*}{$\begin{array}{l}\text { Skor } \\
\text { Akhir } \\
\text { RFM } \\
\end{array}$} & \multirow[t]{2}{*}{ Label pelanggan } \\
\hline & Recency & Frequency & Monetary & & \\
\hline K1 & Baru saja & Jarang & Rendah & 311 & Dormant D \\
\hline $\mathrm{K} 2$ & Baru saja & Jarang & Sedang & 312 & Dormant A \\
\hline K3 & Baru saja & Jarang & Tinggi & 313 & Occational A \\
\hline K4 & Baru saja & Agak sering & Rendah & 321 & Everyday D \\
\hline K5 & Baru saja & Agak sering & Sedang & 322 & Golden D \\
\hline K6 & Baru saja & Agak sering & Tinggi & 323 & Superstar D \\
\hline K7 & Baru saja & Sering & Rendah & 331 & Everyday A \\
\hline K8 & Baru saja & Sering & Sedang & 332 & Golden A \\
\hline K9 & Baru saja & Sering & Tinggi & 333 & Superstar A \\
\hline K10 & Agak lama & Jarang & Rendah & 211 & Dormant E \\
\hline K11 & Agak lama & Jarang & Sedang & 212 & Dormant B \\
\hline K12 & Agak lama & Jarang & Tinggi & 213 & Occational B \\
\hline K13 & Agak lama & Agak sering & Rendah & 221 & Everyday E \\
\hline K14 & Agak lama & Agak sering & Sedang & 222 & Golden $E$ \\
\hline K15 & Agak lama & Agak sering & Tinggi & 223 & Superstar E \\
\hline K16 & Agak lama & Sering & Rendah & 231 & Everyday B \\
\hline K17 & Agak lama & Sering & Sedang & 232 & Golden B \\
\hline K18 & Agak lama & Sering & Tinggi & 233 & Superstar B \\
\hline K19 & Lama & Jarang & Rendah & 111 & Dormant F \\
\hline K20 & Lama & Jarang & Sedang & 112 & Dormant $C$ \\
\hline K21 & Lama & Jarang & Tinggi & 113 & Occational C \\
\hline K22 & Lama & Agak sering & Rendah & 121 & Everyday $F$ \\
\hline K23 & Lama & Agak sering & Sedang & 122 & Golden F \\
\hline K24 & Lama & Agak sering & Tinggi & 123 & Superstar F \\
\hline K25 & Lama & Sering & Rendah & 131 & Everyday C \\
\hline K26 & Lama & Sering & Sedang & 132 & Golden C \\
\hline $\mathrm{K} 27$ & Lama & Sering & Tinggi & 133 & Superstar C \\
\hline
\end{tabular}

Proses mining dengan algoritma Decision Tree C4.5 dimulai dengan menghitung nilai Entropy, Gain, dan Split dari masing - masing atribut data training yang ada sehingga menghasilkan Gain Ratio. Rumus untuk menghitung Entropy, Gain, Split dan Gain Ratio bisa dilihat pada persamaan 1,2,3,4 berikut :

$$
\begin{aligned}
& \operatorname{Entropy}(S)=\sum_{i-1}^{k}-p i * \log _{2} p i \\
& \operatorname{Gain}\left(S_{i} A\right)=\operatorname{Entropy}(S)-\sum_{i=1}^{n} \frac{\left|s_{i}\right|}{|S|} * \operatorname{Entropy}(S) \\
& \operatorname{SplitInfo}\left(s_{*}, j\right)=-\sum_{i=1}^{k} p\left(v_{i} \mid s\right) \log _{2} p\left(v_{i} \mid s\right) \\
& \operatorname{RasioGain}(s, j)=\frac{\operatorname{Gain}(s, j)}{\operatorname{SplitInfo}(s, j)}
\end{aligned}
$$

Dimana :

S : himpunan kasus

A : atribut

$\mathrm{n}$ : jumlah partisi atribut $\mathrm{A}$

$\left|\mathrm{S}_{\mathrm{i}}\right|$ : jumlah kasus pada partisi ke-i

|S|: jumlah kasus dalam S 
Atribut yang memiliki Gain Ratioterbesar dipilih untuk membuat simpul akar. Selanjutnya menghitung nilai Entropy,Gain dan Split dari masing-masing atribut dengan menghilangkan atribut yang telah dipilih sebelumnya. Atribut yang memiliki Gain Ratio terbesar dipilih untuk membuat simpul internal. Ulangi perhitungan tersebut hingga semua atribut memiliki kelas. Jika semua atribut/pohon sudah memiliki kelas, maka tampilkan pohon keputusan awal dan generate aturan keputusan awal. Tahapan alur kerja proses algoritma Decision Tree C4.5 diilustrasikan pada Gambar 2 berikut.

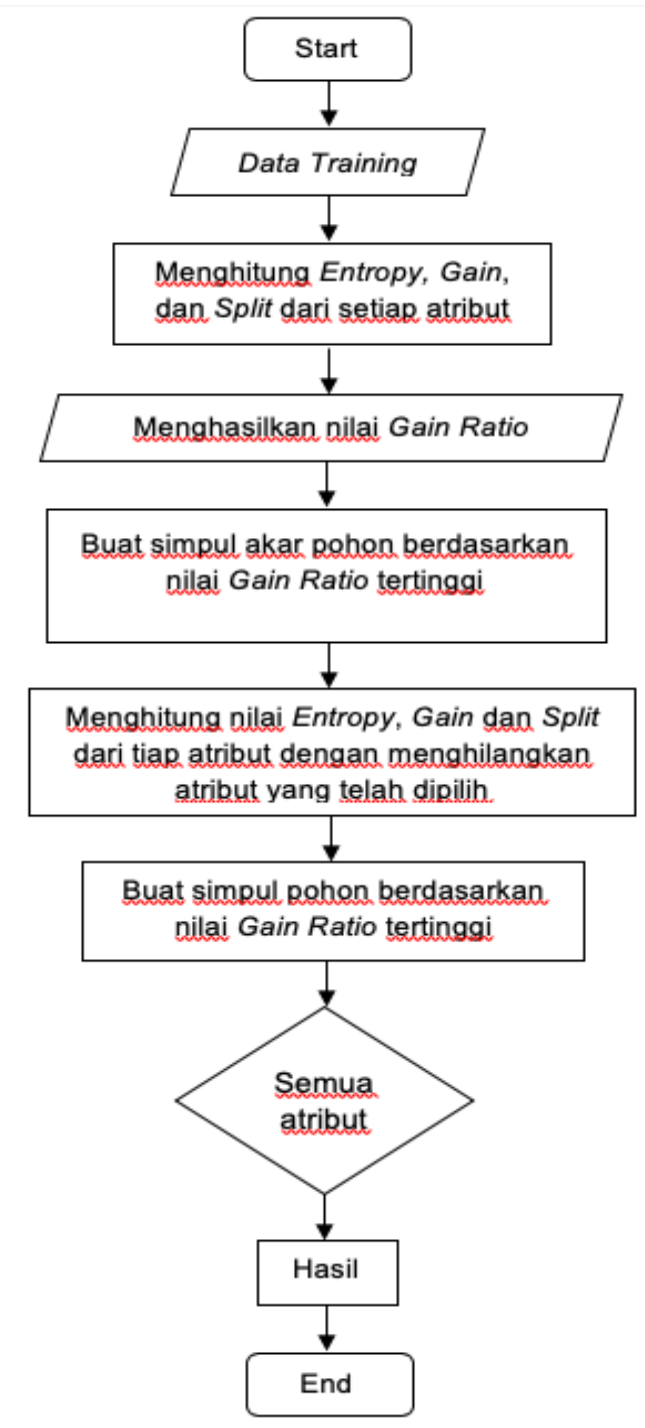

Gambar 2. Flowchart Decision Tree C4.5

Nä̈ve Bayes merupakan teknik prediksi berbasis probabilitas sederhana yang berdasar pada penerapan aturan bayes dengan asumsi ketidaktergantungan yang kuat. Selain itu Naïve Bayes juga dapat menganalisa variable - variabel yang paling mempengaruhinya dalam bentuk peluang (Prasetyo, 2012).

Berikut merupakan persamaan dari teorema Bayes :

$P(H \mid X)=\frac{P(X \mid H) \cdot P(H)}{p(X)}$

Keterangan :

$\mathrm{X}$ : Data dengan class yang belum diketahui $\mathrm{H}$ : hipotesis data $\mathrm{X}$ merupakan suatu class spesifik

$\mathrm{P}(\mathrm{H} \mid \mathrm{X}) \quad$ : Probabilitas akhir bersyarat suatu hipotesis $\mathrm{H}$ terjadi jika diberikan bukti $\mathrm{X}$ terjadi

$\mathrm{P}(\mathrm{H}) \quad$ : Probabilitas awal (priori) hipotesis $\mathrm{H}$ terjadi tanpa memandang bukti apapun

$\mathrm{P}(\mathrm{X} \mid \mathrm{H}) \quad$ : Probabilitas sebuah bukti $\mathrm{X}$ terjadi akan mempengaruhi hipotesis $\mathrm{H}$

$\mathrm{P}(\mathrm{X}) \quad$ : Probabilitas awal (priori) bukti X terjadi tanpa memandang hipotesis/bukti yang lain 


\section{Evaluasi}

Confusion Matrix adalah suatu metoda yang biasanya digunakan untuk melakukan perhitungan akurasi pada konsep data mining. Berikut ini adalah table confusion matrix :

Tabel 5. Confusion Matrix

\begin{tabular}{llll}
\hline & & Kelas Hasil Prediksi \\
& & \\
& & Tidak $(+)$ & Ya $(-)$ \\
\hline \multirow{2}{*}{ Kelas Asli } & Tidak $(+)$ & TP $($ True Positive $)$ & FN (False Negative $)$ \\
& Ya $(-)$ & FP (False Positive $)$ & TN (True Negative) \\
\hline
\end{tabular}

Evaluasi dengan confusion matrix menghasilkan nilai accuracy, precision, dan recall. Accuracy dalam klasifikasi adalah persentase ketepatan record data yang diklasifikasikan secara benar setelah dilakukan pengujian pada hasil klasifikasi [9], sedangkan precision adalah proporsi kasus yang diprediksi positif yang juga positif benar pada data yang sebenarnya. Recall adalah proporsi kasus positif yang sebenarnya yang diprediksi positif secara benar. Rumusnya sebagai berikut :

$$
\begin{aligned}
& \text { 1. } \text { Recall = } \mathrm{TP} /(\mathrm{TP}+\mathrm{FN}) \\
& \begin{array}{ll}
\text { 2. } \text { recision } & =\mathrm{TP} /(\mathrm{TP}+\mathrm{FP}) \\
\text { 3. } \text { ccuracy } & =(\mathrm{TP}+\mathrm{TN}) /(\mathrm{TP}+\mathrm{FP}+\mathrm{FN}+\mathrm{TN})
\end{array}
\end{aligned}
$$

\section{Keterangan :}

1. TP (True Positive) adalah jumlah record positif yang diklasifikasikan sebagai positif

2. FP (False Positive) adalah jumlah record negative yang diklasifikasikan sebagai positif

3. FN (False Negative) adalah jumlah record positif yang diklasifikasikan sebagai negative

4. TN (True Negative) adalah jumlah record negative yang diklasifikasikan sebagai negative

\section{Hasil dan pembahasan}

Mengidentifikasi karakter pelanggan UD.Mawar Sari melalui proses segmentasi pelanggan berbasis RFM (Recency, Frequency, Monetary) menghasilkan kelas pelanggan Dormant, Everyday, Golden dan Superstar. Penerapan model prediksi customer churn diuji coba pada 4 data yaitu :

1. Data uji dengan data pelanggan kelas Dormant (2284 kasus)

2. Data uji dengan data pelanggan kelas Everyday (104 kasus)

3. Data uji dengan data pelanggan kelas Golden (259 kasus)

4. Data uji dengan data pelanggan kelas Dormant (183 kasus)

Berikut adalah hasil kinerja algoritma Decision Tree C4.5 pada setiap kelas pelanggan (Tabel 6) dan grafik pada Gambar 3.

Tabel 6. Hasil Kinerja Algoritma Decision Tree C4.5

\begin{tabular}{llll}
\hline Kelas Pelanggan & $\begin{array}{l}\text { Decision Tree C4.5 } \\
\text { Recall }\end{array}$ & Precision & Accuracy \\
\hline Dormant & $97.51 \%$ & $75.18 \%$ & $76.18 \%$ \\
Everyday & $100 \%$ & $99.04 \%$ & $99.04 \%$ \\
Golden & $100 \%$ & $98.84 \%$ & $98.84 \%$ \\
Superstar & $96.15 \%$ & $99.43 \%$ & $95.63 \%$ \\
\hline
\end{tabular}

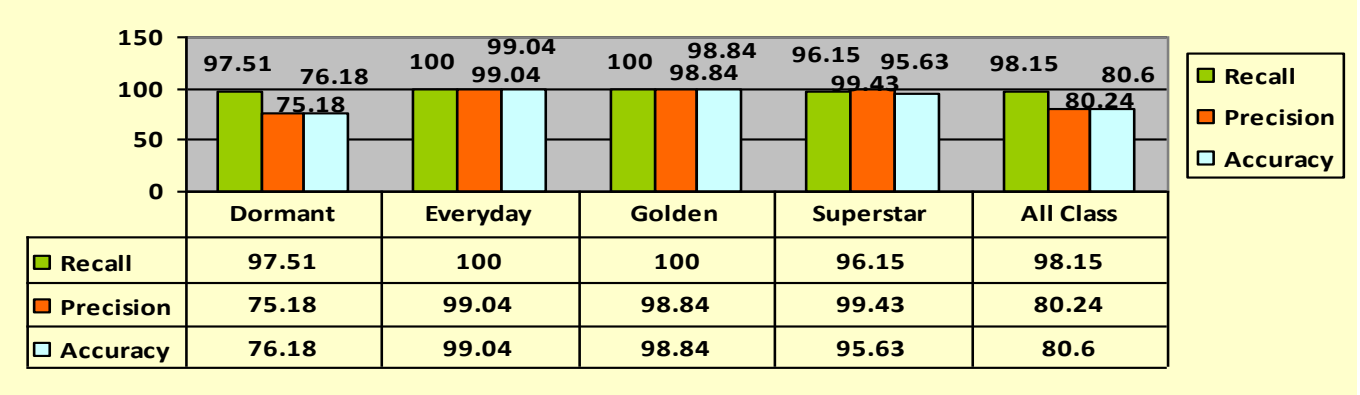

Gambar 3. Grafik Kinerja Algoritma Decision Tree C4.5 
Berikut adalah hasil kinerja algoritma Naïve Bayes pada setiap kelas pelanggan (Tabel 7) dan grafik pada Gambar 4.

Tabel 7. Hasil Kinerja Algoritma Nä̈ve Bayes

\begin{tabular}{llll}
\hline \multirow{2}{*}{ Kelas Pelanggan } & $\begin{array}{l}\text { Nä̈ve Bayes } \\
\text { Recall }\end{array}$ & Precision & Accuracy \\
\hline Dormant & $97.51 \%$ & $75.18 \%$ & $76.18 \%$ \\
Everyday & $100 \%$ & $99.04 \%$ & $99.04 \%$ \\
Golden & $100 \%$ & $98.84 \%$ & $98.84 \%$ \\
Superstar & $96.15 \%$ & $99.43 \%$ & $95.63 \%$ \\
\hline
\end{tabular}

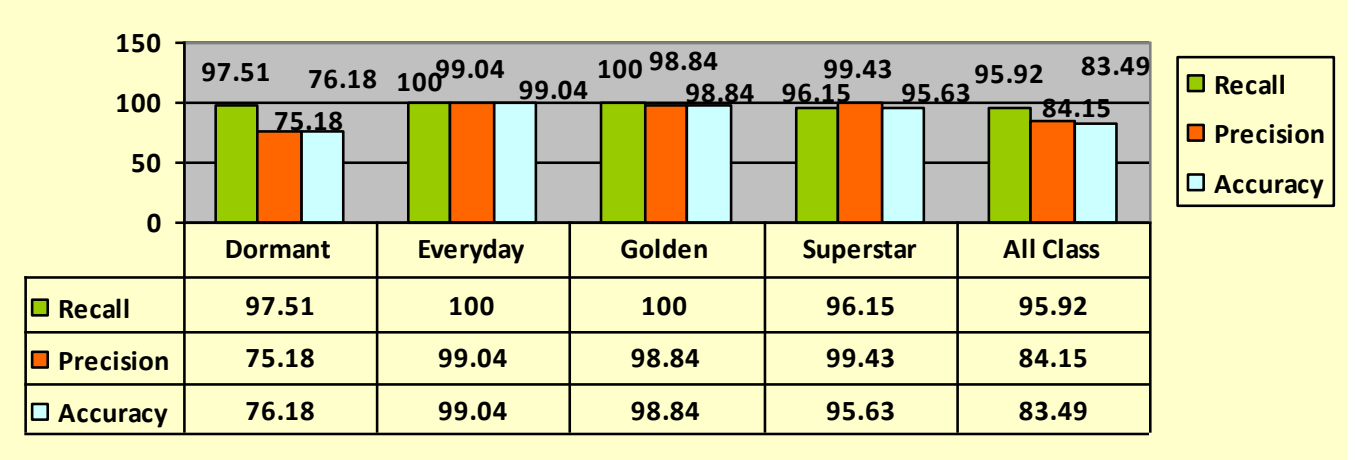

Gambar 4. Grafik Kinerja Algoritma Nä̈ve Bayes

Menganalisa hasil perhitungan recall, precision dan accuracy dari Algoritma Decision Tree C4.5 dan Naïve Bayes dapat disimpulkan bahwa kelas pelanggan UD. Mawar Sari yang berpotensi churn adalah kelas pelanggan dormant. Untuk mengetahui lebih detail bagaimana karakter pelanggan dormant yang berpotensi churn, perlu dilakukan perhitungan recall, precision dan accuracy pada masing-masing label pelanggan dormantyang dimiliki oleh UD. Mawar Sari yaitu dormant A, dormant B, dormant D, dormant E dan dormant $\mathrm{F}$.

Penerapan model prediksi customer churn diuji coba pada 4 data kelas pelanggan dormant yaitu:

1. Data uji dengan data pelanggan kelas Dormant A (65 kasus)

2. Data uji dengan data pelanggan kelas Dormant B (6 kasus)

3. Data uji dengan data pelanggan kelas Dormant D (894 kasus)

4. Data uji dengan data pelanggan kelas Dormant E (176 kasus)

5. Data uji dengan data pelanggan kelas Dormant F (249 kasus)

Tabel 8. Hasil kinerja AlgoritmaDecision Tree C4.5 pada kelas pelanggan Dormant

\begin{tabular}{llll}
\hline Kelas Pelanggan & $\begin{array}{l}\text { Decision Tree C4.5 } \\
\text { Recall }\end{array}$ & Precision & Accuracy \\
\hline Dormant $A$ & $100 \%$ & $98.46 \%$ & $98.46 \%$ \\
Dormant $B$ & $100 \%$ & $16.67 \%$ & $16.67 \%$ \\
Dormant $D$ & $100 \%$ & $79.31 \%$ & $79.31 \%$ \\
Dormant $E$ & $100 \%$ & $26.70 \%$ & $26.70 \%$ \\
Dormant $F$ & $0 \%$ & $0 \%$ & $84.34 \%$ \\
\hline
\end{tabular}

Tabel 9. Hasil kinerja AlgoritmaNä̈ve Bayes pada kelas pelanggan Dormant

\begin{tabular}{llll}
\hline Kelas Pelanggan & $\begin{array}{l}\text { Nä̈ve Bayes } \\
\text { Recall }\end{array}$ & Precision & Accuracy \\
\hline Dormant $A$ & $100 \%$ & $98.46 \%$ & $98.46 \%$ \\
Dormant $B$ & $100 \%$ & $16.67 \%$ & $16.67 \%$ \\
Dormant $D$ & $100 \%$ & $79.31 \%$ & $79.31 \%$ \\
Dormant $E$ & $100 \%$ & $26.70 \%$ & $26.70 \%$ \\
Dormant $F$ & $0 \%$ & $0 \%$ & $84.34 \%$ \\
\hline
\end{tabular}




\section{Simpulan dan saran}

Dari penjelasan di atas,, adapaun simpulan yang dapat disampaikan pada penelitian ini antara lain:

1. Dari proses segmentasi pelanggan menggunakan pemodelan RFM (Recency, Frequency, Monetary) dapat diketahui karakteristik pelanggan UD. Mawar Sari. Dari proses segmentasi tersebut dapat diketahui kelas pelanggan yang dimiliki oleh UD. Mawar Sari yaitu kelas Dormant, Everyday, Golden dan Superstar.

2. Jumlah pelanggan terbesar yang dimiliki UD. Mawar Sari selama 2 tahun perioda Juli 2015 - Mei 2017 berada di kelas Dormant yaitu pelanggan dengan karakteristik yang memiliki nilai Recency,Frequency,dan Monetary.

3. Jumlah pelanggan terkecil dimiliki oleh UD. Mawar Sari selama 2 tahun perioda Juli 2015 - Mei 2017 berada di kelas Everyday yaitu pelanggan dengan karakteristik yang memiliki peningkatan transaksi dan kategori nilai Monetary rendah atau sedang.

4. Algoritma Decision Tree C4.5 dan Nä̈ve Bayes menghasilkan kinerja yang sama pada setiap kelas pelanggan. Hasil kinerja pada kelas pelanggan Dormant yaitu recall $97.51 \%$, precision $75.18 \%$, dan accuracy $76.18 \%$. Hasil kinerja pada kelas pelanggan Everyday yaitu recall 100\%, precision $99.04 \%$, dan accuracy 99.04\%. Hasil kinerja pada kelas pelanggan Golden yaitu recall 100\%, precision $98.84 \%$, dan accuracy 98.84\%. Hasil kinerja pada kelas pelanggan superstar yaitu recall 96.15\%, precision 99.43\%, dan accuracy $95.63 \%$

5. Kinerja algoritma Decision Tree C4.5 dan Nä̈ve Bayes pada semua kelas pelanggan menghasilkan recall, precision dan accuracy yang berbeda, dimana kinerja algoritma Naïve Bayes lebih baik dari kinerja algoritma Decision Tree C4.5. Hasil kinerja Decision Tree C4.5 yaitu recall 98.15\%, precision $80.24 \%$, dan accuracy $80.6 \%$ dan hasil kinerja Naïve Bayes yaitu recall 95.92\%, precision $84.15 \%$, dan accuracy $83.49 \%$.

6. Kinerja algoritma Decision Tree C4.5 dan Naïve Bayes dalam prediksi customer churn sangat baik pada data uji yang berisi data dengan kemiripan atau kesamaan karakteristik sedangkan pada data uji yang berisi data dengan keragaman karakteristik, kinerja algoritma Decision Tree C4.5 dan Naïve Bayes dalam prediksi customer churn mengalami penurunan.

7. Kinerja algoritma Nä̈ve Bayes lebih baik dibandingkan kinerja algoritma Decision Tree C4.5 dalam prediksi customer churn yang menggunakan data uji gabungan semua kelas pelanggan.

8. Dilihat dari hasil perhitungan precision, recall dan accuracy pada setiap kelas pelanggan maka dapat disimpulkan bahwa pelanggan UD. Mawar Sari yang berpotensial churn adalah kelas pelanggan Dormant. Pelanggan dengan label Dormant B, Dormant E dan Dormant F adalah pelanggan yang paling berpotensi untuk churn.

Dari simpulan yang telah dijabarkan peneliti menyampaikan saran sebagai berikut: 1) Model segmentasi pelanggan dan prediksi dapat mempertimbangkan variable - variable lainnya seperti lamanya berlanggan berlangganan data demografi pelanggan maupun data dari kompetitor seperti harga dan jenis produk yang ditawarkan oleh kompetitor. Dengan adanya variable tambahan diharapkan hasil segmentasi pelanggan dan hasil prediksi dapat lebih akurat, dan 2) Untuk penelitian berikutnya, memprediksi customer churn dapat menggunakan algoritma klasifikasi lainnya seperti Artificial Neural Network, Support Vector Machine, Nearest Neighbor, dll. Dengan harapan hasil kinerja algoritma lainnya dapat dibandingkan dengan hasil kinerja algoritma pada penelitian ini.

\section{Daftar Rujukan}

a a G. B. Ariana, "Customer Segmentation Dengan Metode Self Organizing Map ( Studi Kasus : UD . Fenny )," Neuron, vol. 2, no. 1, pp. 1-7, 2011.

A. Chorianopoulus, Effective CRM using Predictive Analytics. Wiley, 2009.

E. C. Murphy and M. A. Murphy, Leading On the Edge Of Chaos : The 10 Critical Elements for Success in Volatile Times. USA: Prentice Hall Press, 2002.

E. Prasetyo, Data mining Mengolah Data Menjadi Informasi Menggunakan Matlab. Penerbit ANDI Yogyakarta, 2014.

E. Prasetyo, Data mining : Konsep dan Aplikasi Menggunakan Matlab. Penerbit ANDI Yogyakarta, 2013.

F. Gorunescu, Data Mining Concept Model and Techniques. Berlin: Springer, 2011. 
G. Klepac, Developing Churn Models Using Data mining Techniques and Social Network Analysis. USA: IGI Global, 2015.

J. Burez and D. Van den Poel, "Handling class imbalance in customer churn prediction," Expert Syst. Appl., vol. 36, no. 3 PART 1, pp. 4626-4636, 2009.

M. Listiana, Sudjalwo, and D. Gunawan, "Perbandingan Algoritma Decision Tree (C4.5) Dan Naïve Bayes Pada Data Mining Untuk Identifikasi Tumbuh Kembang Anak Balita (Studi Kasus Puskesmas Kartasura)," Informatika, vol. 1, no. 1, p. 18, 2015.

P. S. Venatesan, Data Mining and Warehousing. New Age International (P) Limited, 2007.

R. Govindaraju, T. Simatupang, and T. A. Samadhi, "Perancangan Sistem Prediksi Churn Pelanggan,” Tek. Inform., vol. 9, no. 1, pp. 33-42, 2008.

V. L. M. Oliviera, “Analytical Customer Relationship Management in Retailing Supported by Data Mining Techniques," University of Porto, 2012.

V. L. M. Oliviera, "Predicting Partial Customer Churn using Markov for Discrimination for Modeling First Purchase Sequence," University of Porto, 2012.

W. Buckinx and D. Van Den Poel, "Customer base analysis: Partial defection of behaviourally loyal clients in a non-contractual FMCG retail setting," Eur. J. Oper. Res., vol. 164, no. 1, pp. 252-268, 2005.

Y. Liu and Y. Zhuang, "Research Model of Churn Prediction Based on Customer Segmentation and Misclassification Cost in the Context of Big Data," J. Comput. Commun., vol. 3, no. 3, pp. 87-93, 2015. 